\title{
THEOLOGICAL MODERATION IN THE ISLAMIC BOARDING SCHOOL (PESANTREN): PHENOMENOLOGICAL PROPHETIC SOCIAL STUDY IN PESANTREN IN EAST JAVA
}

\author{
Mustari Bosra \\ State University of Makassar \\ Tidung, Rappocini, Makassar, South Sulawesi, Indobesia \\ E-mail: mustari.bosra@unm.ac.id \\ Umiarso \\ University of Muhammadiyah Malang \\ Sumbersari, Lowokwaru, Malang, East Java, Indonesia \\ E-mail: umiarso@umm.ac.id
}

\begin{tabular}{|c|c|c|}
\hline Received & Revised & Approved \\
$12 / 04 / 2020$ & $27 / 06 / 2020$ & $30 / 06 / 2020$ \\
\hline
\end{tabular}

DOI: https:// doi.org/10.32332/akademika.v25i1.2369

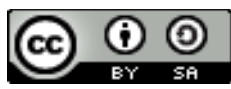

Theological Moderation In The Islamic Boarding School (Pesantren):

Phenomenological Prophetic Social Study In Pesantren In East Java

Licensed Under a Creative Commons Attribution-ShareAlike 4.0

International License

\begin{abstract}
This article examines the construction of the religious moderation in pesantren which emphasizes the values framework that underlies it. Therefore, this research focused on the basic framework of theological normative values of the religious moderation in Islamic boarding schools (pesantren) in East Java. Based on this focus, this research emphasized a qualitative approach with a phenomenological type. The findings of this research review that the religious moderation built by the pesantren is based on divine awareness. Reasonably that their attitudes and actions
\end{abstract}


continue to represent religious-spiritual values. Therefore, every dimension of their life is inseparable from Qur'anic ethics, including religious views, attitudes and actions. This is what the researcher termed aas theological moderation. The implication is not only to dynamize religious life in a society with various movements and beliefs but also to empower rationality (reason) in the pesantren, so that the educational system in the pesantren is also influenced by this religious moderation.

Keywords: Islamic Education, Moderation, and Phenomenology

\section{A. Introduction}

This article examines the construction of the religious moderation in the oldest Islamic education institution in Indonesia, namely pesantren. The discourse of the religious moderation strengthens along with the development of radicalism in Indonesian society, including educational institutions (Islam). Therefore, various researches on moderation in Islamic education emerged, such as Siswanto's research which analyzes the values of Islamic moderation in the curriculum; ${ }^{1}$ Ekawati, et al., conducted research on moderating forms of Islamic higher education curriculum; ${ }^{2}$ research by Rusli, et al., also describes/reviews the moderation of Islam in the perspective of the academic community; 3 research by Mahrus, et al., examines the moderation of Islamic education in ancient manuscripts; 4 There are even researches which review the moderation of Islamic education on the historical trajectory of Indonesian education, such as Najib's research. ${ }^{5}$ Meanwhile, researches on the religious moderation in pesantren have also been conducted by researchers. One of which is the

1 Siswanto, "The Islamic Moderation Values on the Islamic Education Curriculum in Indonesia: A Content Analysis", Jurnal Pendidikan Islam 8, no. 1 (2019): 121-152.

2 Ekawati, et al., "Moderation of Higher Education Curriculum in Religious Deradicalization in Indonesia", Journal of Education in Muslim Society 6, no. 2 (2019): 169-178.

${ }^{3}$ Ris'an Rusli, et al., "Islamic Moderation in Higher Education", Opcion Journal 35, no. 89 (2019), 2899-2921.

${ }^{4}$ Erwin Mahrus, et al., "Messages of Religious Moderation Education in Sambas Islam Manuscripts”, Madania: Jurnal Kajian Keislaman 24, no. 1 (2020): 39-48.

5 Abdul Najib, "Patterns of Islamic Education Moderation in Indonesian History", Didaktika Religia: Journal of Islamic Education 6, no. 1 (2018): 107-124. 
researches by Zubaedi, et al.,6 Fathurochman, et al., ${ }^{7}$ or Ni'am, ${ }^{8}$ as well as Somantri \& Dahwadin. ${ }^{9}$ These researches focus and place more emphasis on the construction of the religious moderation established by pesantren.

Therefore, the normative values that make up the religious moderation are designed independently of the theological anchor discourse. Such as the researches by Ahdar, et al. ${ }^{10}$ and also Hasan ${ }^{11}$ which tend to unravel the cultivation of the religious moderation in pesantren. This means that the theological anchor discourse is often left untouched by researchers of Islamic education in traditional (salaf) and modern (khalaf) pesantren. Even though the theological anchor has the opportunity to foster the religious moderation in every pesantren person (individual). Although on the other hand, research by Marzuki, et al., states that moderation in pesantren emerges and develops from the application of core values of multiculturalism. ${ }^{12}$ Meanwhile, Aziz's research is slightly different in that moderation arises from the knowledge of figh and ushul figh possessed by the students. ${ }^{13}$

${ }^{6}$ Zubaedi, et al.," The Construction of Religious Moderation Values in Islamic Boarding Schools (Pesantren): Efforts to Prevent Radicalism in Indonesia", Journal of Talent Development and Excellence 12, no. 2s (2020): 3613-3623.

7 Irwan Fathurrohman, "Revitalization of Islamic Boarding School Management to Foster the Spirit of Islam Moderation in Indonesia', Jurnal Pendidikan Islam 8, no. 2 (2019): 239-258.

8 Syamsun Ni'am, "Pesantren: The Miniature of Moderate Islam in Indonesia", Indonesian Journal of Islam and Muslim Societies 5, no. 1 (2015): 111-134.

${ }^{9}$ Muhamad Dani Somantri \& Dahwadin, "The Message of Religious Moderation in Tanbih Qadiriyah Naqsyabandiyah (TQN) Pondok Pesantren Suryalaya", Teosofia: Indonesian Journal of Islamic Mysticism 8, no. 1 (2019): 51-68.

${ }^{10}$ Ahdar, et al., "Moderation and Mainstream of Pesantren or Madrasah Education", Kuriositas: Media Komunikasi Sosial dan Keagamaan 13, no. 1 (2020): 14-37.

${ }^{11}$ Mohammad Hasan, "Wasatiyyah Islam in The Pesantren Islam Education Tradition Framework", Karsa: Journal of Social and Islamic Culture 26, no. 2 (2018): 177-194.

12 Marzuki, et al., "Multicultural Education in Salaf Pesantren and Prevention of Religious Radicalism in Indonesia", Cakrawala Pendidikan: Jurnal Ilmiah Pendidikan 39, no. 1 (2020): 12-25.

${ }^{13}$ Abdul Aziz, "Akar Moderasi Beragama di Pesantren: Studi Kasus di Ma'had Aly Sukorejo Sitoubondo dalam Terbentuknya Nilai-Nilai Moderasi Beragama", arRisalah: Media Keislaman, Pendidikan dan Hukum Islam 18, no. 1 (2020): 142-157. 
It needs to be admitted, the moderation that instilled in educational institutions such as pesantren will have an impact on the diversity of society. In Zarkasyi's research, it is implied that the religious moderation can present a dynamic and tolerant society like Indonesian society. ${ }^{14}$ Reasonably, from the "middle way" patterns and concepts, pesantren could play a more dynamic socio-religious role. Thus, the pace of community development which is motivated by religious reality is highly dependent on the moderation attitude of the people, including the implementation of the education system.

\section{B. Focus and Research Methods}

Based on the construction of the research context, this research focused on theological values that become the background for the construction of the religious moderation in pesantren. The pesantren studied as a research site was Pesantren Miftahul Ulum Suren Kalisat in East Java. This framework raises a research question, how is the construction of the religious moderation based on theological values in Pesantren Miftahul Ulum Suren Kalisat in East Java? Therefore, this research used a qualitative approach in understanding these theological values with a phenomenological type. For data collection techniques, this research used more observations which were also supported by interviews. Meanwhile, the data analysis used by the researcher was interactive data analysis by Miles and Hubermann.

\section{Religious Moderation in Pesantren}

Moderate attitude is an action that forms a balance between belief and tolerance. The belief that is owned remains on the path or axis of tolerance towards other beliefs. Therefore, moderate diversity is a naturalistic, scientific belief, and full of tolerance values. Therefore, thoughts and attitudes of moderation are intermediate actions between radicalism and liberalism. From the attitude of religious moderation, empowerment patterns towards the internalities and externalities of the

14 Hamid Fahmy Zarkasyi, “Appraising The Moderation Indonesian Muslims with Special Reference to Muhammadiyah and Nahdlatul Ulama", Addin: Media Dialektika Ilmu Islam 12, no. 1 (2018): 1-30. 
pesantren will emerge. Like empowerment in women, ${ }^{15}$ or creating a noble personality, ${ }^{16}$ thus there is research that states that because of the existence of Muslim schools -read: Islamic boarding schools (pesantren)- Indonesian society becomes a moderate society. ${ }^{17}$

From this framework, it is very clear that moderation is a form of action that supports human values. Rabasa, et al., define that the moderate ummah -read: the Muslim community- is a community whose thoughts and actions support the freedom of worship, gender equality, and are in opposition to terrorism and acts of violence. ${ }^{18}$ Pesantren Miftahul Ulum Suren since the beginning of its establishment, -namely in 1952 in which was founded by KH. Ahmad Mudzhar, under the name of Pesantren arRohmah-, has embodied the value of tolerance towards the adherents of other religions, the tradition of egalitarian relations between men and women; and has strongly challenged the acts of terrorism. In fact, it often pioneers humanitarian movements through pesantren education programs such as gender-based critical studies of the yellow book (kitab kuning), or even on religious plurality.

These limitations and phenomena show that the religious moderation is still designed through empowerment and development of human resource competencies. Pesantren Miftahul Ulum Suren also has a moderate view that is pro-democracy and cares for human values. Within this view there are constructions of egalitarian relations, religious plurality, and tolerance. All of these constructions are in line with Islamic religious principles and norms. It is reasonably for them to highly uphold human humanity, thus their attitudes and actions often oppose violence and recognize the harmony of social life. The principle of education that is applied in pesantren is the equality between male-female or old-young

${ }^{15}$ Mustari Bosra \& Umiarso, “The Mainstreaming Women's Empowerment in Gender Islamic Boarding School”, Journal of Talent Development and Excellence 12, no. 1 (2020): 2866-2881.

${ }^{16}$ Muhammad Chairul Huda, et al., "Pesantren and Takzir in Indonesia: Lawrence Friedman's Legal System Perspective", Jurnal Penelitian 17, no. 1 (2020): 4354.

${ }^{17}$ Muhammad Zuhdi, “Challenging Moderate Muslims: Indonesia's Muslim Schools in the Midst of Religious Conservatism", Religions 9, no. 10 (2018): 1-15.

18 Angel Rabasa, et al., Building Moderate Muslim Networks (Santa Monica: RAND Corporation, 2007), 66. 
human selves. Because humans are declared to have the same duties and obligations before Allah, and what distinguishes them is only their level of taqwa.

The concept of moderation that is practiced by Pesantren Miftahul Ulum Suren is to describe more human values; and in fact it is able to have a positive influence on the educational order of the pesantren and society. Reasonably, if Sutrisno's research concludes that educational institutions could be positioned as laboratories for the religious moderation through a socio-religious approach to religion and society. ${ }^{19}$ This means that the religious moderation taught and applied by Pesantren Miftahul Ulum Suren encourages the growth of tolerance in the pesantren community. In a broad context, the pattern of moderation in Islamic religiousness also has strong implications in society, especially for the strengthening of radicalism. ${ }^{20}$

In fact, the moderation in these pesantren comes mainly from religious-ethics as stated in the Qur'an. The final estuary of these dynamics forms actions that require proper rights, namely actions that give proper rights by taking a middle path so as not to go beyond the boundaries of Islamic law. But, their actions remain within the framework of the freedom to innovate that eliminates extremity or excessive action. The attitudes commonly seen in Pesantren Miftahul Ulum Suren are strongly tied to the mission of Islam -namely the representation of QS. al-Anbiya verse 107. The characters that appear also cannot be separated from Islamic values such as the attitude to prioritize moderation -the representation of QS. alBaqarah verse 143-, the attitude to always stand side with the truth (hanif) the manifestation of QS. ar-Rum verse 30-, and the attitude to continuously uphold justice -the spirit of QS. al-Maidah verse 8 .

They raise these characters to manifest and present themselves as the best in the community. This ideal hope contributes to shaping humanist attitudes, liberation, and also transcendence; all of them appear with the spirit of applying QS. Ali Imran verse 110. In fact, attitudes and actions arise from ethical-religious awareness, thus it will strengthen religious

${ }^{19}$ Edy Sutrisno, "Aktualisasi Moderasi Beragama di Lembaga Pendidikan”, Jurnal Bimas Islam 12, no. 2 (2019): 323-348.

${ }^{20}$ Nuraan Davids, "Islam, Moderation, Radicalism, and Justly Balanced Communities", Journal of Muslim Minority Affairs 37, no. 3 (2017): 309-320. 
nuances with an attitude of moderation. The implication is that the behavior that continues to be displayed by the students of Pesantren Miftahul Ulum Suren supports the persistence of rahmatan lil 'alamin's religious attitude. Modest, cooperative, tolerant, not extreme (right or left) and pluralist behaviors in the aspect of religious behavior without neglecting the basic principles of Islam. Even today, pluralism is prioritized by all religious communities, including Christians. ${ }^{21}$

The attitudes and actions of the students of Pesantren Miftahul Ulum Suren illustrate that they have practiced the principles and values of moderation that are inseparable from the ethical-religious found in the Qur'an. Within this framework, it is reflected in the basic character of Islam that distinguishes the manhaj of Islamic moderation from the existing methodologies in other ideologies, schools and philosophies. The moderating attitude of the pesantren's religiosity is an attitude and action of rejection of the dimensions of the extremities in the form of tyranny, evil, and dehumanization. It is nothing but a reflection of the original human fithrah which is pure and has not been contaminated by negative influences. However, as the conclusion of the article of Faiqah \& Pransiska - the formulation of the functionalization of attitudes and moderation measures in the order of social and state life is a very important factor. ${ }^{22}$ This means that the religious moderation in pesantren needs to be placed in the middle of real society life; not in the form of a discourse containing theoretical concepts.

The students of Pesantren Miftahul Ulum Suren believe that in the concept of moderation of Islamic diversity, ethical assertiveness emerges. As there is truth in the midst of evil; justice in the midst of injustice; [attitide of] positioning oneself in the middle of the extremities, and rejecting exaggerations will emerge. This is because exaggerations in religious action will conflict with the principle of moderation of the pesantren itself - such as partiality of understanding, attitudes and actions

21 Priyantoro Widodo \& Karnawati, "Moderasi Agama dan Pemahaman Radikalisme di Indonesia", Pasca: Jurnal Teologi dan Pendidikan Agama Kristen 15, no. 2 (2019): 9-14.

22 Nurul Faiqah \& Toni Pransiska, "Radikalisme Islam VS Moderasi Islam: Upaya Membangun Wajah Islam Indonesia yang Damai", al-Fikra: Jurnal Ilmiah Keislaman 17, no. 1 (2018): 33-60. 
at one of the poles of religious liberal or extreme conservative action. The current religious moderation is needed to answer the problems of society, namely extremism and radicalism, such as in the conclusion in Khotimah's article. ${ }^{23}$ Even in a research by Cheung, et al., - it reveals that the involvement of religion in the order of social life is very influential. ${ }^{24}$

Thus, the religious moderation has the power to build/establish a tolerant and humanist society. It is also able to bring out a fair attitude by standing on one of the two weights. In the end, the condition for religious imbalance does require a middle way of Islam that is comprehensive, balanced, just and moderate. Pesantren Miftahul Ulum Suren cuts down the understanding of intolerant and discriminatory diversity. However, on the one hand, they are aware that creating students [of the society] who are moderate and tolerant in religion cannot be separated from social society. They believe that the division of Islam in society is moderate, liberal, fundamental, and extreme as it cannot be separated from the political constellation and also different judgments. In fact, according to the members of the pesantren, Islam only has one division, namely Islam rahmatan li al-'alamin.

Although the concept of the religious moderation constructed by Pesantren Miftahul Ulum Suren is stuck in an "in-between" position, this concept of moderation is not completely compromised by mixing up all the elements, nor does it isolate itself by refusing to meet other elements. This character in their paradigm is a proportional attitude in viewing all problems with a balanced attitude; or attitude that is neither extreme nor liberal. To realize this construction, they try to open space for critical interpretation of the knowledge of the books being studied. This pattern is recognized by Alabdulhadi in his research which suggests that the value of tolerance needs to be described in religious textbooks. ${ }^{25}$ Reasonably for the

${ }^{23}$ Husnul Khotimah, "Internalisasi Moderasi Beragama dalam Kurikulum Pesantren", Rabbani: Jurnal Pendidikan Agama Islam 1, no. 1 (2020): 62-68.

${ }^{24}$ Chris Hin Wah Cheung, et al., "Religious Engagement and Attitudes to the Role of Religion in Society: Their Effect on Civic and Social Values in a Asian Context", British Journal of Religious Education 40, no. 2 (2018): 158-168.

${ }^{25}$ Maali Mohammaed Jassim Alabdulhadi, "Religious Tolerance in Secondary Islamic Education Textbooks in Kuwait", British Journal of Religious Education 41, no. 4 (2019): 422-434. 
discourse that appears on the surface of the pesantren to be framed by the values of religious moderation.

\section{Moderation in Religion in Pesantren}

The attitude of moderation manifested in Pesantren Miftahul Ulum Suren cannot be separated from the normative source of Islamic religion (namely the Qur'an). Therefore, the Qur'an has actually been used by millions of Muslims to legitimize their behavior, support wars, nurture hopes, preserve beliefs, and strengthen collective identities in the face of various problems. This means that the position of the Qur'an is very central to Muslims, including the students of Pesantren Miftahul Ulum Suren. Reasonably that the Qur'an is used to inspire and legitimize their attitude of religious moderation. Ethically, as stated by Afsaruddin in his research, the Qur'an (namely in QS. Al-Baqarah verse 143 and QS. Al-Maidah verse 66 ) is the standard and ethical behavior of religious moderation. ${ }^{26}$ From this attitude framework, the researcher can call it as a humanist-religious moderation; that is, a kind of moderation which points to the development of humanist values based on qur'ani ethics.

Regardless of this attitude, in real terms, Muslims -in this context are Pesantren- are strongly tied to the Qur'an. For this reason, the massive use of the Qur'an has implications for the self-effort of Pesantren Miftahul Ulum Suren to interpret the verses according to their point of view and approach. Even now, in unraveling the meaning of the verses of the Qur'an, they are very consistent with the paradigmatic of moderation. Generally, in East Java, the interpretation of the verses of the Qur'an can be grouped into two opposite slices, namely: the traditionalist and the modernist group. However, this pesantren (Pesantren Miftahul Ulum Suren) is able to adopt traditionalist and modernist group methodologies to find a moderate interpretation methodology. Indeed, as concluded in Hariyanto's research, the Qur'an can be freely interpreted according to the surrounding context in order to give enlightenment . ${ }^{27}$ However, [in] its

26 Asma Afsaruddin, "The Hermeneutics of Inter-Faith Relations: Retrieving Moderation and Pluralism as Universal Principles in Qur'anic Exegeses", Journal of Religious Ethics 37, no. 2 (2009): 331-354.

27 Ishak Hariyanto, "Hermeneutika al-Qur'an Muhammed Arkoun", el-Umdah: Jurnal Ilmu al-Qur'an dan Tafsir 1, no. 2 (2018): 130-144. 
epistemological face, the categorization in understanding the sources of Islamic law is designed in two parts, namely: first, the contextual face of Islam, recognizing differences and diversity, as well as various different spaces of truth; and second, the textual face, expecting uniformity (antiplurality) and claiming that only they are right. ${ }^{28}$

In this condition, through the moderation methodology, Pesantren Miftahul Ulum Suren provides a strong theological foundation for their intellectuality. This pattern is functioned so that the socio-cultural manifestations of the Islamic religious face that are manifested do not tend to be salafism-conservative or also modernist-liberal. They realize that the dynamics of diversity in today's Islamic society need to be responded to with a religious attitude that could create a safe and harmonious life order. The religious attitude that must be built is a moderate and tolerant attitude by sticking to the normative values of the Qur'an. To practice this attitude an atmosphere of social, economic, or even religious diversity was created through discussion forums for students, seminars, and the real life of students in the community inside and outside the pesantren.

This religious moderation leads to the transformation of the Islamic movement of Pesantren Miftahul Ulum Suren in social life. There are several characteristics of their moderation, among others: first, the ability to combine the traditional (salafiyah) and modernist-reformer (tajdid) dimensions. Salafiyah in this context is interpreted as an attitude of returning to the first generation in understanding religion and returning all religious issues to the Qur'an and the Sunnah of the Prophet. While tajdid is an attitude of adjusting understanding of -or with the patterns and pace of- the times with the spirit of liberation from the shackles of stagnation and blind imitation (taklid). Second, the ability to balance between constant (tsawabit) and changeful (mutaghayyirat) religious doctrines.

Third, the ability cultivate a critical attitude, so that they are more vigilant in order to avoid the wrong way of understanding Islam. There are at least three models that represent wrong attitudes -these attitudes are highly avoided by Pesantren Miftahul Ulum Suren, namely: a stagnant,

28 Stephen Sulaiman Schwarts, Dua Wajah Islam: Moderatisme vs Fundamentalisme dalam Wacana Global, Translater: Hodri Ariev (Jakarta: Blantika, 2007), xi. 
old-fashioned, and constant understanding of Islamic doctrines (tajmid); distorting understanding, deviating, and obscuring the essence of Islamic doctrines (tamyii'), as practiced by syncretic communities; and also partial understanding and separation of one doctrinal dimension from another (tajziah). And fourth, the ability to understand Islam universally and comprehensively, covering all dimensions, such as spiritual (imani, spiritual), social (ijtima'i), political (siyasi), jurisprudential (tasyri'i), as well as civilization and cultural (hadlari) dimensions.

From the concept of the religious moderation, students of Pesantren Miftahul Ulum Suren -when they see the problems of religious social relations- are not partial. It is clear that their moderation has an impact on human and religious social relations. This is because the orientation put forward by the pesantren is an integration orientation, namely humanistreligious. A partialistic orientation only forms one dimension and weakens the other; this is what Fernros worries about in his research. ${ }^{29}$ If only the human dimension (which) is formed, it will cause social upheaval such as violence in the name of religion. Even in Indonesia, religion is often used as a legitimator for the actions and political interests of certain communities. ${ }^{30}$

Without a sense of skepticism, efforts to defend oneself and the truth of the values believed are recommended actions. However, this attitude does not negate the value of truth believed by other communities, especially those with different views. Like the dynamics of the Islamic movements around Pesantren Miftahul Ulum Suren which have an extreme orientation (FPI, HTI, LDI, JT) that do not make themselves (the students of the pesantren) to be fiercer. Although sometimes at the level of discourse and action, these extreme Islamic movements appear tougher than mainstreaming movements such as Muhammadiyah and NU. Pesantren Miftahul Ulum Suren remains moderate (recognizes the existence of other communities, is tolerant of different views, and never

${ }^{29}$ Henrik Friberg-Fernros, "The Explanatory Power of the Soul: Why Liberals Should Seriously Consider Dualism", Journal of Religious Ethics 48, no. 1 (2020): 101121.

${ }^{30}$ Cornelis Lay, "Kekerasan Atas Nama Agama: Perspektif Politik”, JSP: Jurnal Ilmu Sosial dan Ilmu Politik 13, no. 1 (2009): 1-19; Yuangga Kurnia Y., "Fenomena Kekerasan Bermotif Agama di Indonesia", Kalimah: Jurnal Studi Agama dan Pemikiran Islam 15, no. 2 (2017): 205-217. 
forces a will by force), so that socio-religious relations in the pesantren environment remain conducive.

The attitudes of the religious moderation are admitted by the students of Pesantren Miftahul Ulum Suren to have emerged from the spirit of translating the divine awareness in them. Based on the researcher's analysis, there is an attitude of moderation that comes from the verses of the Qur'an such as respecting pluralism and opening space for interaction (born from QS. al-Hujurat verse 13); religious expression with a polite and wise attitude (sourced from QS. al-Nakhl verse 125); opening religious spaces in line with the principle of providing facilities according to ability not burdening the people- (inspired by QS. al-Baqarah verses 185 and 286; as well as QS. al-Taghabun verse 16). According to them, the emergence of a harsh and extreme religious attitudes is caused by an attitude that does not heed the rules in practicing religious doctrines. Therefore, when practicing these doctrines, it only creates confusion and religious anomalies. Even when a religious anomaly arises, in the conclusion of Kurniawan \& Margiansyah's research, it is said that they no longer need other value sets such as egalitarian values, humanism, or justice. ${ }^{31}$

The students of Pesantren Miftahul Ulum Suren are aware that there is a big role played by the Islamic movements, but they have kept a "time bomb" which could explode at any time destroying the ideals of public peace. The emergence of this problem arises from the womb of the plurality of religious movements that have a vision, mission and concept of movement. This plurality often creates sharp fractions between one religious movement and another. This condition is very worrying for Pesantren Miftahul Ulum Suren, because it can cause an erosion of peace and become an obstacle to the realization of the religious moderation. In this context, the pesantren is trying to build awareness, that the view of the religious movement who "feels" to have the ability to carry the burden alone -as "the single fighter" - is a big mistake.

Basically, the character of Islamic doctrines is very moderate, but it is covered by the radical and liberal paradigm and attitude of certain

${ }^{31}$ Fuat Edi Kurniawan \& Defbry Margiansyah, "Aktivisme Gerakan Keagamaan dalam Konteks Kebudayaan: Antara Penegakan Syariat dan Anomali", Jurnal Sosiologi Reflektif 14, no. 1 (2019): 41-57. 
communities. Therefore, the application of the religious moderation in pesantren is not an easy matter. This is because Pesantren Miftahul Ulum Suren needs pioneering efforts so that moderation becomes a reference for the thinking, attitude and action of its students. Reasonably that they (the students of the pesantren) are required to distance themselves from fanaticism and absolutism towards their own beliefs or paradigms. This attitude also raises awareness of the unity of humanity, so that it is difficult for them to accuse other communities of being heretics (tabdi'), shirks (tasyrik), or infidels (takfir). If this attitude is not developed, it is certain that radicalism and religious extremism will develop. Especially if it is elaborated with Wahabism; ${ }^{32}$ and developing verses of violence that are interpreted exclusively. 33

Based on this religious mission, Islamic diversity at Pesantren Miftahul Ulum Suren continues to represent moderate Islamic values. Its religious moderation is strongly tied to the divine consciousness (awareness) which depicts wisdom in analyzing and addressing extreme and liberal points. Starting from that religiosity, the religious moderation attitude of the pesantren emerged and developed to form the militancy of Islamic preaching. It is as if their condition is a reflection of the religiosity of the Muslims themselves which protect the beliefs and religions of other people. Reasonably that other beliefs -such as the existence of Christianity or other religious movements- can live safely and peacefully in the environment around the pesantren. Their principle that we need to underline is the principle of respecting all religions in an egalitarian manner; however they (the students of the pesantren) do not consider all religions as the same.

In fact, the construction of the religious moderation has positive implications for religious social relations in the society. This religious moderation by Pesantren Miftahul Ulum Suren is developed from divine awareness, so that their attitudes and actions continue to apply religiousspiritual values. Therefore, all constructs of their lives cannot be separated

32 Nurjannah, "Faktor Pemicu Munculnya Radikalisme Islam atas Nama Dakwah", Jurnal Dakwah 19, no. 2 (2013): 177-198.

33 Ahmad Asrori, "Radikalisme di Indonesia: Antara Historisitas dan Antropisitas", Kalam: Jurnal Studi Agama dan Pemikiran Islam 9, no. 2 (2015): 253268. 
from the ethical dimension of the Qur'anic -divine values- including religious views, attitudes, and actions. This means, the attitude of the religious moderation that they build is a logical consequence of this divine consciousness (awareness). This is what the researcher termed as theological moderation.

\section{E. Implications of the Religious Moderation on Pesantren Education}

Pesantren Miftahul Ulum Suren, through its religious moderation, continues to proclaim that theologically humans have a noble and equal position. The position of humans is not determined by ethnic groups, languages and socially distinguishing religions. Thus, human virtue is determined by the level of taqwa, not the social reality that underlies it. In this context, the religious moderation encourages recognition of all existences and treatises, beliefs, and religious civilizations and other nations. This attitude, according to the conclusions of Yanti \& Witro's research, is said to be a solution to resolving conflicts against differences in beliefs and religions. ${ }^{34}$ Because, on the one hand, it is also able to develop the ability to -accommodate modernity, be tolerant of differences, and be liberal. ${ }^{35}$ Thus, it encourages an integrative development pattern between the profane and sacred dimensions; between humanity and divinity.

The implication is that Pesantren Miftahul Ulum Suren in carrying out its education system integrates the roles of reason and revelation. Epistemologically, they try to unite the dimensions of the burhani and the bayani; hence they also combine the ontologic side of Islamic boarding schools (pesantren), namely between the written book (qauliyyah) and the verses that lie in the universe (qauniyyah). In this context it can be said that the religious moderation fosters methodological wisdom on the scientific foundation of the pesantren. Therefore, they have faith that the totality of Islamic diversity does not hinder the relationship (linkage) of the modern dynamics (science and technology) with the spirit of religiosity. The

34 Betria Zarpina Yanti \& Doli Witro, "Islamic Moderation as A Resolution of Different Conflicts of Religion", Andragogi: Jurnal Diklat Teknis Pendidikan dan Keagamaan 8, no. 1 (2020): 446-457.

35 Ahmad Agis Mubarok \& Diaz Gandara Rustam, “Islam Nusantara: Moderasi Islam di Indonesia", Journal of Islamic Studies \& Humanities 3, no. 2 (2018), 153-168. 
conclusion of Yusuf's research also states that Islamic moderation includes dimensions of aqidah, sharia (islamic laws) and sufism (tasawuf) whose orientation is to recognize the truth of reason and revelation, even intuition. 36

Reasonably that the religious moderation also influences the pesantren scholarship, such as openness to accept diversity. This attitude is reflected in the wisdom of responding to various schools of thoughts, as well as in various religions. They are aware that the emanation of the meaning of the Qur'an is not uniformly accepted by the rationality of the people, because it is very dependent on the broad aspects of the insight and ideology of each ummah. However, differences do not prevent Pesantren Miftahul Ulum Suren from cooperating with other parties based on humanitarian principles. Their principle, religious knowledge is very open to critical dialogue; even having the principle of believing in the truest Islamic religion does not mean that you have to insult the religion of other people or even disbelieve them.

They are aware, reason and revelation have very important roles in the scientific construction of the pesantren. Revelation is revealed as a guide to decipher the meaning of life, as well as a source of inspiration in developing science. Reason is able to understand revelation (qauliyyah and qauniyyah) with the help of the five senses as its epistemological tool. Thus, there is a close relationship between reason and revelation to bring out the truth that comes from Allah. Although on the one hand, the validity of the role of the reason in Islamic thought is still being debated. ${ }^{37}$ However, the capacity and authority of the reason greatly determine the style of thinking on religious diversity, especially in the midst of social realities. The implication is that if the space for rationality is opened wide, it will give birth to a rational religious style; or vice versa. Therefore, Pesantren Miftahul Ulum Suren binds the capacity and authority of the reason more with Qur'anic ethics. Based on this phenomenon, it can be confirmed that

${ }^{36}$ Achmad Yusuf, "Moderasi Islam dalam Dimensi Trilogi Islam (Akidah, Syariah, dan Tasawuf)", al-Murabbi: Jurnal Pendidikan Agama Islam 3, no. 2 (2018): 203-216.

37 Reynaldi Adi Surya, “Kedudukan Akal dalam Islam: Perdebatan Antara Mazhab Rasional dan Tradisional Islam", Ushuluna: Jurnal Ilmu Ushuluddin 5, no. 1 (2019), 1-21. 
Islam is an articulation of religious identity, as is concluded by Umar's research. ${ }^{38}$

Their goal is to integrate this so that there is no more stagnation in scientific development in Islam. In fact, Nasution has long challenged the dogmatic problems and stagnation in Islamic thinking. He even considered that the cause of decline experienced by Muslims on the historical stage is due to the stagnation of thought. ${ }^{39}$ Indeed, it is like the conclusion of Aprison's research that the reason (scientific source tool) and revelation (religious source) cannot be contradicted.40 From this ideal, Pesantren Miftahul Ulum Suren tries to rationalize the understanding of Muslims who are very dogmatic and not "down to earth". One of them is by optimizing the potential and authority of the reason while still being guided by religious ethical values (Islam); intellectual potential integrated with religious ethics.

The pesantren explains vulgarly that the revelations brought by the Prophet Muhammad essentially only provide the basics of education read: science. Meanwhile, the duty of the reason is to explain the essence conveyed by the revelations and elaborate it with the reality of humanity and experience. The function of the reason in understanding revelation is termed as dynamic-creation; while in the realm of Islamic studies it is called as ijtihad. This potential integration style is also capable of developing scientific creations on the stage of Islamic civilization. Even now, there have been efforts to integrate it, namely: through the process of Islamizing science; through an integrative-interconnective process that refers to philosophical dimensions such as the ontologic, epistemological, and axiological sides; and through integrative-interconnective process which breaks down into three domains, namely: integrative-

38 Ahmad Rizky Mardhatillah Umar, "A Genealogy of Moderate Islam: Governmentality and Discourses of Islam in Indonesia's Foreign Policy", Studia Islamika: Indonesian Journal for Islamic Studies 23, no. 3 (2016): 399-433.

${ }^{39}$ Harun Nasution, Akal dan Wahyu dalam Islam (Jakarta: UI Press, 1986), 7-9.

40 Wedra Aprison, "Mendamaikan Sains dan Agama: Mempertimbangkan Teori Harun Nasution", Jurnal Pendidikan Islam 4, no. 2 (2015): 241-259. 
interdependent, integrative-complement, and integrative-qualitative domains. ${ }^{41}$

Interestingly, Pesantren Miftahul Ulum Suren teaches that the reason has a very high position in developing science. In fact, it is also able to influence the diversity of Muslims through the interpretation it produces. Therefore, the pesantren invites its students to think and use their rationality while remaining within the ethical boundaries of the Qur'anic. Meaning, they expect ethical and dignified critical rationality to build a religious attitude. Indeed, there is an agreement that religious rationalization is imperative so that Islamic doctrines are maintained and have a function in modern life. Even now, the scientific tradition leads to scientific unity (wahdat al-ulum); because knowledge is obtained from the reason and revelation (religion). ${ }^{42}$

This growing awareness cannot be separated from the socio-religious problems in society. Such as the emergence of the religious movements with different styles and interpretations of the Qur'an, some of which are conservative and liberal-extreme. Pesantren Miftahul Ulum Suren teaches that when understanding the Qur'an we cannot let go of our reason, but it is necessary to balance the role of the reason which is guided by Qur'anic ethics. In fact, on the one hand, the Qur' an encourages rational creativity in order to trace the qauniyyah verses to lead to the development of science and technology. Therefore, maximizing the function of the reason to understand the qauliyyah (al-Qur'an) and qauniyyah (universe) verses can actually implement the Islamic doctrines of not having a fierce and violent face.

The religious moderation which has implications for scientific construction in the pesantren encourages the development of inclusive-ism. This ism (philosophy) considers the existing isms (philosophies) -or even other religions- to contain the truth. In fact, it does not rule out the possibility that it can provide benefits for themselves or others. Religious tolerance is what continues to be articulated in the form of a religious attitude. Shihab in this realm states, to get to the point of being inclusive of

${ }^{41}$ Fathul Mufid, "Islamic Sciences Integration", QIJIS: Qudus International Journal of Islamic Studies 2, no. 2 (2014): 144-160.

${ }^{42}$ Abdul Muhaya, "Unity of Science According to al-Ghazali", Walisongo: Jurnal Penelitian Sosial Keagamaan 23, no. 2 (2015): 311-330. 
religion, it is necessary to openly hear the "truth" of religion -or other isms (philosophies) without sacrificing religious principles. ${ }^{43}$ The inclusive spirit that has Pesantren Miftahul Ulum Suren is the spirit of finding the truth and having dialogue. They are more likely to lead to openness through dialogue in unraveling the scientific truth.

Reasonably that the theological refutation of Pesantren Miftahul Ulum Suren is the basic principle of Islam rahmatan lil alamin; namely the pillars of Islamic moderatism. Therefore, the values embodied in the education system (in the pesantren) do not lead to hatred for other religions, humiliation of non-Muslims, or being hostile to violence. Different views, concepts, or even insights do not become a barrier to interacting within their scientific framework. This attitude is reminiscent of historical facts, as described by Wahid that since the beginning of Islam, it is suggested to embrace non-Muslims -to work together to build society, so naturally Islam is a religion that promotes peace not violence. ${ }^{44}$ Besides, the pesantren have begun to shift the direction of their scientific construction to the integration-interconnection segment. Therefore, the dictum of "maintaining the good old traditions, while taking new, better traditions" (al-muhafadzah ala al-qadim al-salih wa al-akhdhu bi al-jadid al-aslah) is the right step to build the educational system.

The pesantren in implementing religious moderation-based education, for the researcher, is a transformation in their education system. This pattern needs to be developed by all pesantren (traditional (salaf) or modern (khalaf)), especially in their curriculum. At least there is a reason behind it, namely: the need to develop Islamic understanding based on critical dialectics of text and context. The struggle of critical and dynamic texts and contexts will give birth to constructive thoughts, because it frees the interpreter from fanaticism. Even this process will make the text continuously relevant to the context. However, this step requires wide space for the authority of rationality.

${ }^{43}$ Alwi Shihab, Islam Inklusif: Menuju Sikap Terbuka dalam Beragama (Bandung: Mizan, 1997), 35.

44 Abdurrahman Wahid, Islam Kosmopolitan: Nilai-Nilai Indonesia dan Transformasi Kebudayaan (Jakarta: The Wahid Institut, 2007), 44. 


\section{F. Conclusion}

The religious moderation of the pesantren which has implications needs to be firmly tied to divine consciousness (awareness). This attitude will represent wisdom in religion, so that it can unravel and respond to extreme and liberal points. The concept of the religious moderation raises an attitude of tolerance and balance to guide the pesantren members to take contributive actions towards themselves and others. Therefore, the construction of their attitudes and actions in life are strongly tied to Qur'anic ethical values -divine values-, so that their varied attitudes of moderation emerge from the awareness of translating the noble values of Islam. At this time, the religious moderation has formed into the personality of the pesantren members and also in its scientific construction -more integrating the authority of the reason and revelation.

This education system can actually prevent educational subjects -or community subjects- from behaving radically in attitudes and thoughts. The created order of community life is more appreciative of forms of diversity in religions (beliefs) -such as other forms of belief that are believed by others. On the other hand, it contributes to creating science that is integrated with the values of revelation (religion), because the education system strengthens the combination of the reason and revelation in scientific unity[.]

\section{REFERENCES}

Afsaruddin, Asma. "The Hermeneutics of Inter-Faith Relations: Retrieving Moderation and Pluralism as Universal Principles in Qur'anic Exegeses". Journal of Religious Ethics 37, no. 2 (2009).

Ahdar, et al. "Moderation and Mainstream of Pesantren or Madrasah Education". Kuriositas: Media Komunikasi Sosial dan Keagamaan 13, no. 1 (2020).

Alabdulhadi, Maali Mohammaed Jassim. "Religious Tolerance in Secondary Islamic Education Textbooks in Kuwait". British Journal of Religious Education 41, no. 4 (2019).

Aprison, Wedra. "Mendamaikan Sains dan Agama: Mempertimbangkan Teori Harun Nasution". Jurnal Pendidikan Islam 4, no. 2 (2015).

Asrori, Ahmad. "Radikalisme di Indonesia: Antara Historisitas dan Antropisitas". Kalam: Jurnal Studi Agama dan Pemikiran Islam 9, no. 2 (2015). 
Aziz, Abdul. "Akar Moderasi Beragama di Pesantren: Studi Kasus di Ma'had Aly Sukorejo Sitoubondo dalam Terbentuknya Nilai-Nilai Moderasi Beragama". ar-Risalah: Media Keislaman, Pendidikan dan Hukum Islam 18, no. 1 (2020).

Bosra, Mustari \& Umiarso. “The Mainstreaming Women's Empowerment in Gender Islamic Boarding School". Journal of Talent Development and Excellence 12, no. 1 (2020).

Cheung, Chris Hin Wah, et al. "Religious Engagement and Attitudes to the Role of Religion in Society: Their Effect on Civic and Social Values in a Asian Context". British Journal of Religious Education 40, no. 2 (2018).

Davids, Nuraan. "Islam, Moderation, Radicalism, and Justly Balanced Communities". Journal of Muslim Minority Affairs 37, no. 3 (2017).

Ekawati, et al. "Moderation of Higher Education Curriculum in Religious Deradicalization in Indonesia". Journal of Education in Muslim Society 6, no. 2 (2019).

Faiqah, Nurul \& Pransiska, Toni. "Radikalisme Islam VS Moderasi Islam: Upaya Membangun Wajah Islam Indonesia yang Damai". al-Fikra: Jurnal Ilmiah Keislaman 17, no. 1 (2018).

Fathurrohman, Irwan. "Revitalization of Islamic Boarding School Management to Foster the Spirit of Islam Moderation in Indonesia'. Jurnal Pendidikan Islam 8, no. 2 (2019).

Friberg-Fernros, Henrik. "The Explanatory Power of the Soul: Why Liberals Should Seriously Consider Dualism". Journal of Religious Ethics 48, no. 1 (2020).

Hariyanto, Ishak. "Hermeneutika al-Qur'an Muhammed Arkoun". el-Umdah: Jurnal Ilmu al-Qur'an dan Tafsir 1, no. 2 (2018).

Hasan, Mohammad. "Wasatiyyah Islam in The Pesantren Islam Education Tradition Framework". Karsa: Journal of Social and Islamic Culture 26, no. 2 (2018).

Huda, Muhammad Chairul, et al. "Pesantren and Takzir in Indonesia: Lawrence Friedman's Legal System Perspective". Jurnal Penelitian 17, no. 1 (2020).

Khotimah, Husnul. "Internalisasi Moderasi Beragama dalam Kurikulum Pesantren". Rabbani: Jurnal Pendidikan Agama Islam 1, no. 1 (2020).

Kurnia Y., Yuangga. "Fenomena Kekerasan Bermotif Agama di Indonesia". Kalimah: Jurnal Studi Agama dan Pemikiran Islam 15, no. 2 (2017).

Kurniawan, Fuat Edi \& Margiansyah, Defbry. "Aktivisme Gerakan Keagamaan dalam Konteks Kebudayaan: Antara Penegakan Syariat dan Anomali". Jurnal Sosiologi Reflektif 14, no. 1 (2019).

Lay, Cornelis. "Kekerasan Atas Nama Agama: Perspektif Politik". JSP: Jurnal Ilmu Sosial dan Ilmu Politik 13, no. 1 (2009). 
Mahrus, Erwin, et al. "Messages of Religious Moderation Education in Sambas Islam Manuscripts". Madania: Jurnal Kajian Keislaman 24, no. 1 (2020).

Marzuki, et al. "Multicultural Education in Salaf Pesantren and Prevention of Religious Radicalism in Indonesia". Cakrawala Pendidikan: Jurnal Ilmiah Pendidikan 39, no. 1 (2020).

Mubarok, Ahmad Agis \& Rustam, Diaz Gandara. "Islam Nusantara: Moderasi Islam di Indonesia". Journal of Islamic Studies \& Humanities 3, no. 2 (2018).

Mufid, Fathul. "Islamic Sciences Integration". QIJIS: Qudus International Journal of Islamic Studies 2, no. 2 (2014).

Muhaya, Abdul. "Unity of Science According to al-Ghazali". Walisongo: Jurnal Penelitian Sosial Keagamaan 23, no. 2 (2015).

Najib, Abdul. "Patterns of Islamic Education Moderation in Indonesian History". Didaktika Religia: Journal of Islamic Education 6, no. 1 (2018).

Nasution, Harun. Akal dan Wahyu dalam Islam. Jakarta: UI Press, 1986.

Ni'am, Syamsun. "Pesantren: The Miniature of Moderate Islam in Indonesia". Indonesian Journal of Islam and Muslim Societies 5, no. 1 (2015).

Nurjannah. "Faktor Pemicu Munculnya Radikalisme Islam atas Nama Dakwah". Jurnal Dakwah 19, no. 2 (2013).

Rabasa, Angel, et al. Building Moderate Muslim Networks. Santa Monica: RAND Corporation, 2007.

Rusli, Ris'an, et al. "Islamic Moderation in Higher Education". Opcion Journal 35, no. 89 (2019).

Schwarts, Stephen Sulaiman. Dua Wajah Islam: Moderatisme vs Fundamentalisme dalam Wacana Global, Translater: Hodri Ariev. Jakarta: Blantika, 2007.

Shihab, Alwi. Islam Inklusif: Menuju Sikap Terbuka dalam Beragama. Bandung: Mizan, 1997.

Siswanto. "The Islamic Moderation Values on the Islamic Education Curriculum in Indonesia: A Content Analysis". Jurnal Pendidikan Islam 8, no. 1 (2019).

Somantri, Muhamad Dani \& Dahwadin. "The Message of Religious Moderation in Tanbih Qadiriyah Naqsyabandiyah (TQN) Pondok Pesantren Suryalaya". Teosofia: Indonesian Journal of Islamic Mysticism 8, no. 1 (2019).

Surya, Reynaldi Adi. "Kedudukan Akal dalam Islam: Perdebatan Antara Mazhab Rasional dan Tradisional Islam". Ushuluna: Jurnal Ilmu Ushuluddin 5, no. 1 (2019). 
Sutrisno, Edy. "Aktualisasi Moderasi Beragama di Lembaga Pendidikan". Jurnal Bimas Islam 12, no. 2 (2019).

Umar, Ahmad Rizky Mardhatillah. "A Genealogy of Moderate Islam: Governmentality and Discourses of Islam in Indonesia's Foreign Policy". Studia Islamika: Indonesian Journal for Islamic Studies 23, no. 3 (2016).

Wahid, Abdurrahman. Islam Kosmopolitan: Nilai-Nilai Indonesia dan Transformasi Kebudayaan. Jakarta: The Wahid Institut, 2007.

Widodo, Priyantoro \& Karnawati. "Moderasi Agama dan Pemahaman Radikalisme di Indonesia". Pasca: Jurnal Teologi dan Pendidikan Agama Kristen 15, no. 2 (2019).

Yanti, Betria Zarpina \& Witro, Dol.i "Islamic Moderation as A Resolution of Different Conflicts of Religion". Andragogi: Jurnal Diklat Teknis Pendidikan dan Keagamaan 8, no. 1 (2020).

Yusuf, Achmad. "Moderasi Islam dalam Dimensi Trilogi Islam (Akidah, Syariah, dan Tasawuf)". al-Murabbi: Jurnal Pendidikan Agama Islam 3, no. 2 (2018).

Zarkasyi, Hamid Fahmy. "Appraising The Moderation Indonesian Muslims with Special Reference to Muhammadiyah and Nahdlatul Ulama". Addin: Media Dialektika Ilmu Islam 12, no. 1 (2018).

Zubaedi, et al. "The Construction of Religious Moderation Values in Islamic Boarding Schools (Pesantren): Efforts to Prevent Radicalism in Indonesia". Journal of Talent Development and Excellence 12, no. 2s (2020).

Zuhdi, Muhammad. "Challenging Moderate Muslims: Indonesia's Muslim Schools in the Midst of Religious Conservatism". Religions 9, no. 10 (2018). 